\title{
ARTIFnS
}

Universidade de São Paulo,

KELEN PESSUTO

São Paulo, Brasil

\section{O LADO BRICOLEUR DE PEDRO COSTA ${ }^{1}$}

\section{RESUMO}

Neste artigo, analisa-se a evolução do método de filmagem do cineasta português Pedro Costa. Grande admirador do movimento punk dos anos 1970, Costa não esconde a influência que o movimento exerce no seu modo de fazer cinema. A partir da ideia do DIY do it yourself - o diretor torna-se um bricoleur ao se utilizar da técnica da colagem na realização de seus filmes, principalmente na pré-produção. Trata-se aqui da bricolagem enquanto técnica. Desde $O$ Sangue (1989), primeiro longa-metragem de Costa, até Cavalo Dinheiro (2014), o processo de produção do diretor tem progredido em direção a uma maneira de filmar própria e que cada vez mais se aproxima da Antropologia. O termo bricolagem surge consagrado na Antropologia por Lévi-Strauss, ao se referir ao pensamento mítico, contrapondo-o ao científico. No cinema, a figura do bricoleur é representada, especialmente, por Jean-Luc Godard. Procura-se ainda analisar as etapas

palavras-chave

cinema português; movimento punk; bricoleur; antropologia visual; "não" atores. em que consiste o processo de Costa, seu modus operandi, a partir do material extrafílmico que permeia sua obra, como suas entrevistas, escritas e o curso ministrado pelo diretor.

1. Este trabalho contou com o apoio da Fundação de Amparo à Pesquisa do Estado de São Paulo (Fapesp). 


\section{INTRODUÇÃO}

Sua potência é de surgir do nada, ou de um breu tão profundo que a escuridão os dissimula pelos contornos dos becos. Na penumbra, à distância das negociações mais óbvias, seu aparecimento resplende, por isso, de uma luz bem mais intensa (Caiafa 1985, 9).

A frase acima, de Janice Caiafa (1985), escrita na introdução de seu livro sobre o movimento punk no Rio de Janeiro, pode ser usada para se referir não só ao surgimento do movimento em terras cariocas, mas, retirada do contexto, também podemos transpô-la à fotografia ${ }^{2}$ dos filmes de Pedro Costa. Mas, a influência punk nos filmes do diretor não se restringe à aparência, ela está presente, principalmente, na concepção do filme.

Pedro Costa nunca escondeu sua admiração pelo movimento punk. Quando adolescente, embalado pelo som de Sex Pistols e Wire, acompanhado de uma turma de amigos, a qual denomina gangue, Costa teve seus primeiros contatos com os filmes de Jean-Luc Godard e Jean Marie Straub.

Ingressou na Escola Superior de Cinema em 1976, logo após a revolução; o que o animava eram os ideais anarquistas que pairavam, nesse período, entre os estudantes. António Reis, um dos mais importantes cineastas portugueses, que imergiu na representação da ruralidade e da vida campesina, foi um de seus primeiros professores. Conta Costa (2016a) que sempre quis ter feito música, mas ter Reis como professor fez com que ele continuasse a estudar cinema. Na universidade, aprendeu a operar os equipamentos de som, filmagem e montagem, o que lhe permitiu trabalhar nas mais diversas funções antes de realizar seu primeiro longa, $O$ Sangue (1989), exibido no Festival de Veneza.

No contexto do cinema português, Pedro Costa surge como figura decisiva na renovação da chamada Escola Portuguesa, que "[...] ancora-se no cinema de autor onde cada filme de cada realizador vive pela sua própria originalidade" (Barroso e Ribas 2008,146), e cuja consolidação se deu nos anos de 1980. Após o estabelecimento do Estado Novo em 1933, o cinema português se dividiu em três vertentes: o cinema oficial do regime cujos temas eram apolíticos e moralistas - representado, principalmente, por António Lopes Ribeiro; o cinema comercial de entretenimento e o Cinema Novo português, criado como oposição ao regime. No período entre a Revolução de 25 de abril de 1974 e o começo da década de 1980, o cinema português voltou-se às produções coletivas e de documentários,

2. Sua fotografia é marcada pelo mínimo uso de iluminação artificial e pelo uso da sombra como elemento dramático. 
influenciado pelos Cineclubes. Foi somente a partir do final desta década que essa cinematografia se destacou, dado o surgimento de uma nova geração de realizadores, figurando Pedro Costa entre esses nomes.

Segundo os autores:

Com uma crescente importância durante a década de 1990, retoma-se uma diluição da ficção, patente em filmes importantes do cinema português, como os citados Acto da primavera (Manoel de Oliveira, 1963), Belarmino (Fernando Lopes, 1964) ou Trás-os-Montes (António Reis e Margarida Cordeiro, 1977), onde a ficção e o documentário coexistem na criação de algo novo. Para esta diluição concorre a significativa ajuda da introdução do digital - de que é caso paradigmático a obra de Pedro Costa (Barroso e Ribas 2008, 150).

O cinema de Pedro Costa borra a fronteira entre o documentário e a ficção. Até mesmo as obras consideradas ficcionais pelo diretor acabam por concorrer em festivais de documentários.

A ficção cola-se ao documentário, em uma obra híbrida, que dispensa classificações. Para este artigo, interessa menos o gênero no qual a obra resulta do que o modo como Pedro Costa emprega sua metodologia para realizá-la. o foco aqui é desvendar o método de direção adotado por Pedro Costa, que considera seu cinema um cinema de colagem. Uso, neste artigo, o termo bricolagem enquanto técnica.

Seu método não é fixo; Costa está sempre a inovar, a explorar as possibilidades de contato entre seus interlocutores, com novos dispositivos e equipamentos. Cada filme tem seu próprio dispositivo, etapas, equipes e método diferentes.

Nas palavras de Eduardo:

Talvez seja preciso retornar não exatamente à filmografia, procurando nela as matrizes históricas e estéticas ou caçando com lupas a célula-mãe do autor, mas retornar e conhecer cada filme específico, cada sequência, cada plano, sem domesticá-los ou enquadrá-los em determinada definição de conjunto. Conhecer de novo, se for o caso, mas sem reconhecer (Eduardo 2010, 43)

Embora, desde O Sangue (1989) a Cavalo Dinheiro (2014), Costa tenha inovado na maneira de fazer seus filmes, todos eles são permeados pelo uso da 
colagem..$^{3}$ O Sangue foi realizado nos moldes tradicionais do cinema. Com uma grande equipe, equipamentos sofisticados, roteiro ou como o próprio diretor nomina: "um filme dentro do sistema" (Costa 2016a), mesmo assim sua estética e conteúdo destacam-se dos filmes comerciais.

Este artigo analisa a influência da bricolagem nos longas-metragens de Pedro Costa, a partir do DIY - do it yourself, personificado na figura do bricoleur, utilizando não somente os filmes como parâmetro, mas, principalmente, suas entrevistas, seus escritos e o curso do qual participei, em 2016. Ou seja, discute seu modus operandi, o método de realização de seus filmes.

Começo traçando um panorama do uso do termo no movimento punk - que se baseia na filosofia do DIY -, na antropologia e no cinema, para então analisar as etapas do processo de produção do cineasta, que consiste na pesquisa do tema, na escolha e direção dos "não" atores. ${ }^{4}$

\section{A ESTÉTICA PUNK E A BRICOLAGEM}

O movimento punk surgiu, no começo dos anos 1970, concomitantemente, na Inglaterra e nos Estados Unidos, ${ }^{5}$ a partir do estilo musical adotado por bandas como Sex Pistols e Ramones, respectivamente. Momento em que os jovens se viam descontentes com a situação econômica e política, na qual o conservadorismo havia assumido o poder em diversos países e a recessão atingira grande parte da população.

Na Inglaterra, o punk surge como uma reação aos valores ultraconservadores com os quais Margaret Thatcher governava o país e que faziam crescer um sentimento xenófobo e racista entre a população. Os jovens estavam descontentes por não se sentirem representados nas artes, tidas como massificadoras e elitistas, que espelhavam esse sentimento retrógrado.

3. Esta análise não leva em conta seus documentários Onde Jaz o Teu Sorriso? (2001), Ne change rien (2005) e nem seus curtas-metragens.

4. Na análise do cinema iraniano, refiro-me aos atores não profissionais como "não" atores, com o não em itálico, para reforçar minha convicção de que mesmo que não sejam profissionais, nos filmes, eles atuam, fabulam e são dirigidos pelo cineasta. É uma relação de ser e estar que se estabelece durante suas performances. Eles agem como se fossem eles mesmos ou outros personagens. Este tema foi discutido por mim durante o mestrado (Pessuto 2011). O mesmo pode ser dito dos sujeitos que atuam nos filmes aqui analisados de Pedro Costa. Vanda, Ventura, Vitalina, entre outros, são pessoas que Costa encontrou e acabaram fazendo parte de seus filmes, às vezes agindo como se fossem outras pessoas, às vezes agindo como se fossem eles mesmos.

5. Alguns autores afirmam que o surgimento do punk se deu com o show dos Sex Pistols, em Londres, em frente ao atelier da estilista Vivienne Westwood, outros defendem que se iniciou nos Estados Unidos com Ramones (Gallo 2010; Caiafa 1985; Bivar 2001). 
o punk surge como uma atitude rebelde a partir da ideia de se construir uma outra cultura capaz de representar toda a gente: os negros, os imigrantes e as minorias, por meio da música, da literatura, das artes plásticas e da adoção de um visual diferenciado, como fator de identidade.

Em busca de uma autonomia frente à civilização, recusaram-se à adesão aos canais propostos de participação política, afastando-se igualmente dos partidos de esquerda, por quem eram criticados, e assumindo uma independência nas várias instâncias da vida, expressa no lema que o caracteriza Do It Yourself (Gallo 2010, 287).

O lema DIY surge no movimento punk como uma questão política e logo se incorpora à estética e à música, baseado na ideia de que qualquer indivíduo pode participar do processo de criação cultural. É concebido como um processo mais democrático e menos elitista. Como abordarei adiante, Pedro Costa incorpora esse processo democrático em seu cinema, no qual qualquer um pode ser ator, qualquer um pode ser o roteirista.

O visual punk se distingue pela combinação de elementos característicos, que fogem dos padrões da moda. Os adeptos desse visual adotam um estilo agressivo, como jaquetas de couro, calça jeans, com broches, alfinetes, retalhos, símbolos e pregos colados e costurados em suas indumentárias, em detrimento de roupas de marcas e do conservadorismo.

o punk é a quebra de convenções, é a abdicação das normas vigentes em prol de um estilo mais despojado e democratizante. A música punk se caracteriza, na maioria das vezes, por se aproximar do público por intermédio da simplificação de suas letras, que abordam desde questões políticas e sociais (anarquismo, niilismo, desemprego, contestação), até temas como sexo, drogas e diversão. São músicas consideradas fáceis de tocar, por possuírem até três acordes, que adentram na filosofia do DIY, incentivando outros jovens a criarem suas próprias bandas.

Em Portugal, os grupos musicais punks começaram a surgir no final da década de 1970, sendo a banda portuguesa Aqui d'El Rock a primeira a aderir ao estilo musical punk (Lemos 2011). Logo em seguida, outras surgiram. Inclusive, Pedro Costa começou sua carreira artística como músico, integrando uma dessas bandas.

Na Antropologia, o uso do termo bricoleur aparece pela primeira vez em Lévi-Strauss, que usa a expressão bricolagem para explicar os padrões característicos do pensamento mítico, diferenciando-o do científico. Distingue os meios utilizados na técnica da bricolagem e os do cientista (na figura do engenheiro), pois a primeira se vale de meios finitos, do que se 
tem à mão, reutilizando materiais disponíveis, enquanto o engenheiro utiliza matéria-prima, instrumentos criados para certas finalidades. A bricolagem opera com as oportunidades que se apresentam. Assim, os objetos se definem por sua instrumentalidade, na qual "os elementos são recolhidos ou conservados em função do princípio de que 'isso sempre pode servir"' (Lévi-Strauss 1989, 33), sendo que tais elementos possibilitam um extenso conjunto de relações.

Lévi-Strauss chama de bricolagem a ciência "primeira", que evita chamar de primitiva, pois, para ele, não há nada de primitivo na técnica do bricoleur. "Em nossos dias o bricoleur é aquele que trabalha com suas mãos, utilizando meios indiretos, se comparando com os artistas" (Lévi-Strauss 1989, 32). Assim, essa técnica consiste em utilizar os meios que se oferecem no momento para a realização, podendo alcançar resultados "brilhantes e imprevistos" (Lévi-Strauss 1989, 32).

No cinema, Jacques Aumont $(2004,156)$ chama de "improvisadores do espírito" os cineastas que praticam a bricolagem, afirma que eles utilizam "tanto o material mais nobre quanto o mais despojado" e ressalta o uso mais literal da bricolagem entre aqueles que praticam o found footage, que se apropriam de imagens já feitas, em detrimento do registro imagético. Nesse caso, o papel do cineasta está na organização desse material. Como exemplo, apresenta-nos o cinema de Alain Fleischer e de Yervant Gianikian e de Angela Ricci-Lucchi, que realizam suas obras com material já existente.

Ainda para o autor, entre a bricolagem e o cinema hollywoodiano, há um outro nível de experimentação no cinema: o artesanato. 0 cineasta artesão é aquele que, para cada novo projeto, busca "[...] material intelectual e artístico e os meios econômicos e institucionais" (Aumont 2004, 161) próprios, como o caso de Jean-Marie Straub e Danièle Huillet. Ainda na visão de Aumont (2004, 162), "O artesão é, por excelência, aquele que inventa tudo sozinho" que em cada obra utiliza meios e processos diversos.

A bricolagem, no sentido literal como abordado por Aumont, aparece com intensidade nos trabalhos de Jean-Luc Godard, uma das inspirações confessas do cinema de Costa. ${ }^{6}$ Godard trabalha com a ideia da bricolagem imagética, quando utiliza materiais de arquivos, como filmes, fotos, cores, capas de livros e discos; textual, ao citar vários autores e ao utilizar anagramas e intertítulos, já muito explorados pelo autor desde a década de 1980; e a fonética ou sonora, a partir da colagem de sons. A colagem, como um campo de batalhas, em seus filmes, produz a intertextualidade.

6. Pedro Costa encontra inspiração também na obra de Danièle Huillet e Jean-Marie Straub (Gallagher 2009; Gorin 2009). 
Robert Stam (2013), em seu ensaio Do texto ao intertexto, prefere falar sobre intertextualidade e não gêneros ao se referir ao cinema, pois, para o autor, o termo gênero possui um caráter passivo e determinante, enquanto a intertextualidade "[...] é mais ativa, pensando o artista como um agente que dinamicamente orquestra textos e discursos preexistentes" (Stam 2013, 227). Além disso, intertextualidade relaciona outros meios e artes.

Em Histoire(s) du cinéma (1988-98), Godard explora ao máximo a possibilidade da colagem intertextual. Impulsionado pelo uso do vídeo, que proporciona um campo maior de experimentação que a película, o realizador usa fragmentos de filmes, recortes de jornais, pinturas, desenhos, sobreposição de imagens... "[...] todas as combinações, todos os afastamentos ou aproximações próprios para suscitar novas formas e significações" (Rancière 2013, 40).

Desse modo, o sentido da imagem no filme não é somente aquele captado pela câmera, mas a dialética que o confronto entre as imagens produz. 0 método do diretor "[...] se baseia na redistribuição ousada e irreverente da conjugação dos sistemas de signos concorrentes" (Delle Vecche 1996, 114), que é possível, por exemplo, quando o diretor, por meio da colagem, contrasta cores, texturas e formas, para evocar o que não está lá, ou "o que simplesmente existe de forma intangível, irrepresentável" (Delle Vecche 1996, 111).

Já no cinema de Pedro Costa, que costuma se referir a seu método como colagem, a bricolagem aparece na apropriação de materiais, não aqueles já filmados, mas sim encontrados pelo cineasta (2012, 2013, 2016a, 2016b). Tais materiais não são películas impressas - como os autênticos bricoleurs - mas locações, pessoas do bairro, diálogos improvisados, entre outros; renunciando a cenários construídos, atores profissionais e roteiros elaborados. Por isso, Costa faz uma diferenciação entre o criar e o encontrar. Para o cineasta, a colagem para é a união desses materiais, por isso é um bricoleur, que adapta tais materiais e, ao mesmo tempo, um artesão, que possui um método próprio para cada filme. A bricolagem de costa se aproxima mais da concepção do termo na Antropologia, denotando instrumentalidade das oportunidades apresentadas, em detrimento de um instrumento criado para um uso específico, do que de sua concepção de acordo com a teoria do cinema - daquela exposta por Aumont.

Os ideais do movimento punk e do DIY atuam no cinema de Pedro Costa, principalmente no método de concepção de seus filmes. Seja ao escalar "não" atores para tais películas, ao invés de atores profissionais, ou ao promover um método democrático de realização, no qual não impõe um roteiro pré-concebido, mas sim propiciando uma criação conjunta. 
Costa não obedece às regras tradicionais de filmagem (nem dos documentários e nem das ficções). Ele abdica das grandes produções, das equipes numerosas, dos equipamentos sofisticados, em favor de um cinema mais intimista, em que não prevalece a figura do produtor e em que possa ter mais liberdade. "Todas as pessoas que mais gosto acabaram sendo produtores de si próprios, Godard, Jean Rouch, todos eles são pequenas unidades de produção. (António) Reis propunha muito isso e fazia-o próprio" (Costa 2016c).

Os materiais que Pedro Costa diz encontrar são as locações. Primeiramente, Cabo Verde, país que o fez mudar seu modo de fazer filmes, como explicarei adiante; o mesmo deu-se com Fontainhas, bairro de imigrantes no subúrbio de Lisboa. Também os atores de seus filmes são pessoas encontradas no bairro, como Vanda, Ventura e Vitalina; sons, como os ruídos da demolição do bairro de Fontainhas, e diálogos, que são dados pelos atores, entre outros.

Costumo usar o termo colagem porque, enfim, no sentido mais literal, colagem é, por um lado uma maneira de fazer arte muito barata... por exemplo, na pintura, são papéis colados, colagem de materiais encontrados, e isso é aplicado nos filmes que faço, que são sempre com orçamentos muito baixos. Os elementos que utilizo são encontrados, como é muitas vezes nas colagens. Colagens, pelo menos no sentido das artes visuais, artes plásticas... por exemplo, os cubistas faziam muito, com jornais, um bocado de papel de cor [...], e eu também, de certa maneira trabalho muito com materiais encontrados. Eu costumo dizer que nós, durante o processo de rodagem, de preparação, de rodagem de qualquer dos filmes encontramos muitas coisas pelas ruas. Às vezes são pessoas mesmo. Por exemplo, a Vitalina que estava comigo agora, foi uma pessoa, agora uma atriz, que encontramos durante o filme. Nós estávamos à espera de mais um personagem. 0 filme seria uma coisa, depois encontramo-la literalmente na rua e foi mais um elemento que se vai colar ao filme que já existia (Costa 2016b). ${ }^{7}$

Os elementos que Pedro Costa utiliza são encontrados no próprio mundo empírico, de cujas sobras ele também se aproveita, ou do que ele mesmo denomina, "desperdícios da realidade" (Costa 2016b). Costuma trabalhar com o que está à margem da sociedade: o imigrante, o pobre, o desfavorecido pelo sistema.

o que não é exclusividade de seu cinema. O neorrealismo italiano, por exemplo, se apropriava das sobras, das pessoas encontradas nas ruas

7. Áudio da entrevista realizada está disponível. 
(além dos atores profissionais), dos escombros do pós-guerra. Assim como o cinema iraniano, nas figuras de Abbas Kiarostami e Jafar Panahi, que utilizam locações reais, "não" atores e buscam temas inspirados no cotidiano, muitas vezes, desses próprios personagens. 0 que difere o cinema de Pedro costa é que o diretor realiza um processo colaborativo. Tanto os neorrealistas quanto os cineastas iranianos mencionados utilizam a improvisação, mas os enredos não são, geralmente, baseados nas experiências dos próprios "não" atores.

Seu método se aproxima também do cinema curdo, principalmente daquele praticado por Bahman Ghobadi, que nega as grandes produções, os roteiros pré-concebidos, os atores profissionais, os cenários e os estúdios, em favor de um cinema mais documental, no qual participam "não" atores e suas experiências. ${ }^{8}$

\section{BRICOLAGEM NA CONCEPÇÃO}

O primeiro filme de Pedro Costa, O Sangue (1989), foi realizado de modo convencional, ou seja, a partir de um roteiro, com equipe numerosa, câmera $35 \mathrm{~mm}$, equipamentos sofisticados, plano de filmagem, atores profissionais e financiamento do Instituto Português de Cinema (IPC).

o primeiro e principal aspecto da bricolagem, enquanto técnica, começa a aparecer no cinema de Pedro Costa já na concepção de seus filmes, isto é, na pré-produção, a partir de Casa de Lava (1994).

Foi durante a realização de Casa de Lava que Pedro Costa mudou completamente seu jeito de trabalhar, influenciado, principalmente, pelo campo com o qual deparou em Cabo Verde. ${ }^{9}$

Pedro Costa pretendia filmar de maneira tradicional, mas deixou-se afetar pela paisagem e pelas pessoas locais, o que o fez abandonar o roteiro prévio de seu filme e a boicotar as filmagens, pois sentiu que não era um filme dentro do mainstream que queria realizar. "Quando cheguei a Cabo Verde, conheci pessoas que se comportavam, que se moviam, agiam e falavam ao contrário do que tinha lido, visto e pensado à distância" (Artecapital n.d.). Sendo assim, o roteiro escrito anteriormente havia se tornado obsoleto, o que o fez mudar completamente seu plano de trabalho.

8 A relação entre o cinema de Bahman Ghobadi e Pedro Costa está sendo desenvolvida em minha tese de doutorado.

9 Cabo Verde foi colônia portuguesa do século XV até sua independência, em 1975. Era o principal sítio para o comércio de escravos e serviu como entreposto comercial e de provisionamento por estar na rota marítima entre Portugal e Brasil. 
O diretor deixava a equipe dormindo e partia acompanhado de seu técnico de som para conhecer pessoas e recolher histórias: "Saia para conversar com as pessoas na rua" (Costa 2016a). Mas esse não foi seu primeiro contato com a região. Dois anos antes das filmagens, o diretor havia visitado Cabo Verde, como uma 'viagem de preparação' para o filme, como assim denomina sua pesquisa de campo. ${ }^{10}$ (Costa 2013)

Em entrevista ao portal Artecapital, Costa conta como o caderno que levou para apontamentos sobre a filmagem acabou tendo outro propósito, durante sua segunda ida a campo já para a rodagem:

Perdi-me completamente quando cheguei ao Fogo e comecei a colar nas folhas quadriculadas retratos das mulheres de Chã das Caldeiras, uma aldeia mesmo no sopé do vulcão. Fui colando também recortes de notícias dos jornais, fait-divers, fotografias de revistas, postais, pequenos fragmentos de textos ou imagens que tinham a ter a ver com o filme, ou com a história que eu começava a concretizar naquela terra. Eram apontamentos alusivos, nada muito direto, eram coisas mais da ordem da associação poética (n.d.).

Seu filme foi se construindo por meio dessas ideias associativas, e o que seria uma coisa acabou se transformando em outra, a partir do momento em que o diretor se deu à liberdade de ousar, de romper com o processo do cinema tradicional e permitir que o caderno substituísse o roteiro.

Num guião será sempre pretensioso ou até ofensivo citar Ésquilo ou referir um desenho do Paul Klee para descrever uma personagem. Aqui podemos pôr o poeta Desnos a falar crioulo e esse tipo de encontro pode ser afirmado e sublinhado sem reservas (Costa 2013,2).

O resultado foi publicado no livro Casa de Lava - Caderno (2013), no qual Costa leva ao extremo a colagem ao sobrepor, contrapor e associar fotografias, poemas, pinturas, cartões postais, cores, recortes de jornal e depoimentos. Uma espécie de caderno de campo de Costa, em forma de scrapbook, o qual o diretor chama de "fac-símile" (Artecapital, n.d.).

10 o trabalho de Pedro Costa aproxima-se da Antropologia visual, principalmente da metodologia utilizada por Jean Rouch ao realizar suas etnoficções, tema este que será abordado em meu próximo artigo. 


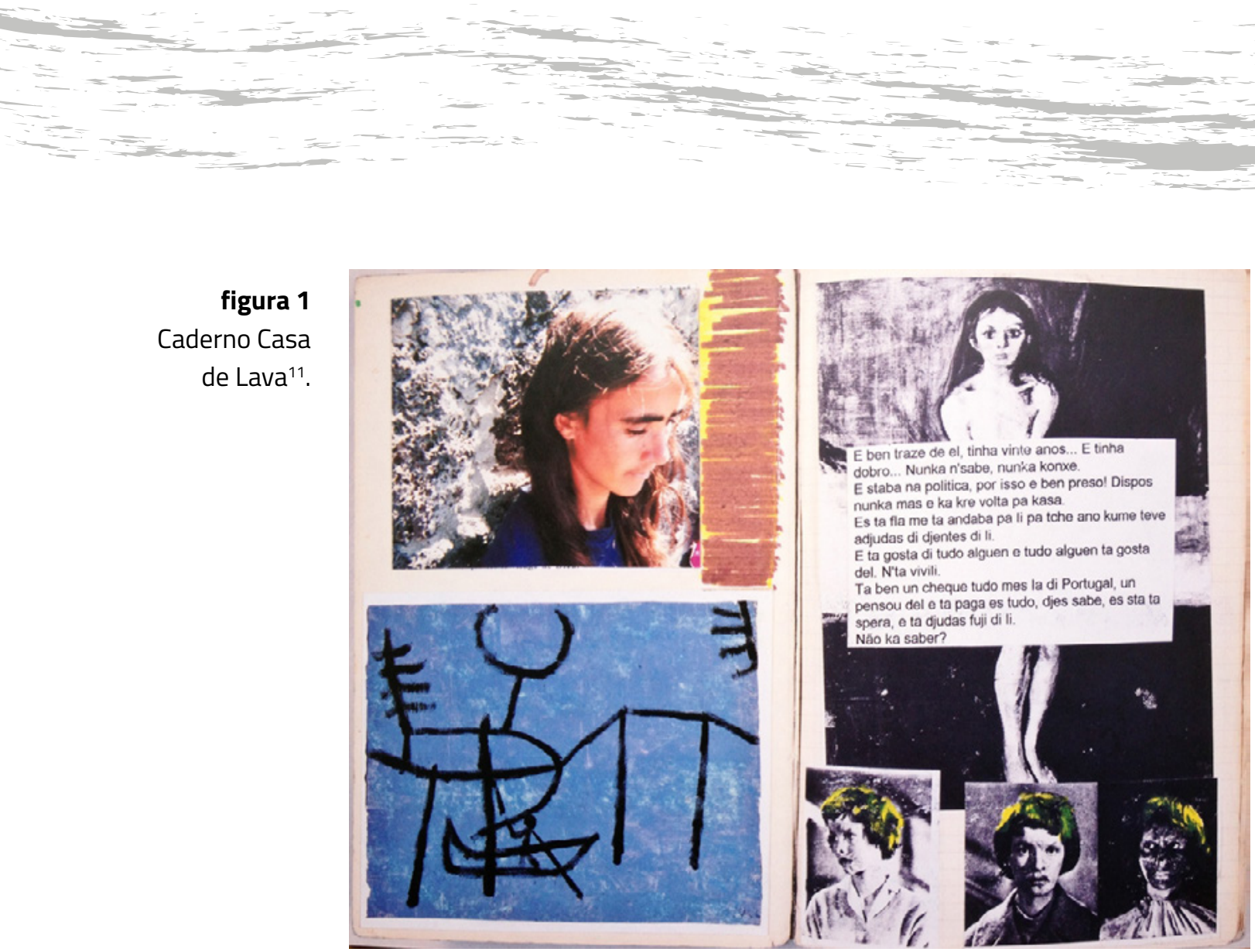

o roteiro original, que foi utilizado para conseguir financiamento e no qual toda a equipe de produção havia baseado seu planejamento e escolha de equipamentos, era baseado no filme I Walked with a Zombie (Jacques Tourneur 1943), pelo qual Pedro Costa tem intensa admiração (Costa 2013). Mas acabou se transformando na experiência de Mariana (Inês de Medeiros), neste país que é um mistério para ela e onde procura a autodescoberta, por meio do contato com os habitantes locais e com o cenário vulcânico. A personagem representa aqui o próprio diretor, a descoberta de seu novo método, o encontro com o povo cabo-verdiano, a música, e, porque não, sua paixão $0^{11}$ pelo país, traduzida pelo amor platônico de Mariana por Leão. ${ }^{12}$

11. Em suas entrevistas, cursos e nos próprios filmes de Pedro Costa, é nítido perceber que o interesse pela cultura e povo de Cabo Verde emana de um sentimento de fascínio pelo tema.

12. Leão (Isaach de Bankolé), o personagem cabo-verdiano de Casa de Lava, sofre um acidente ao cair da grua onde trabalha em Lisboa. Após o ocorrido, ele é transferido em coma para sua casa em Cabo Verde e a enfermeira Mariana o acompanha na sua convalescência. 

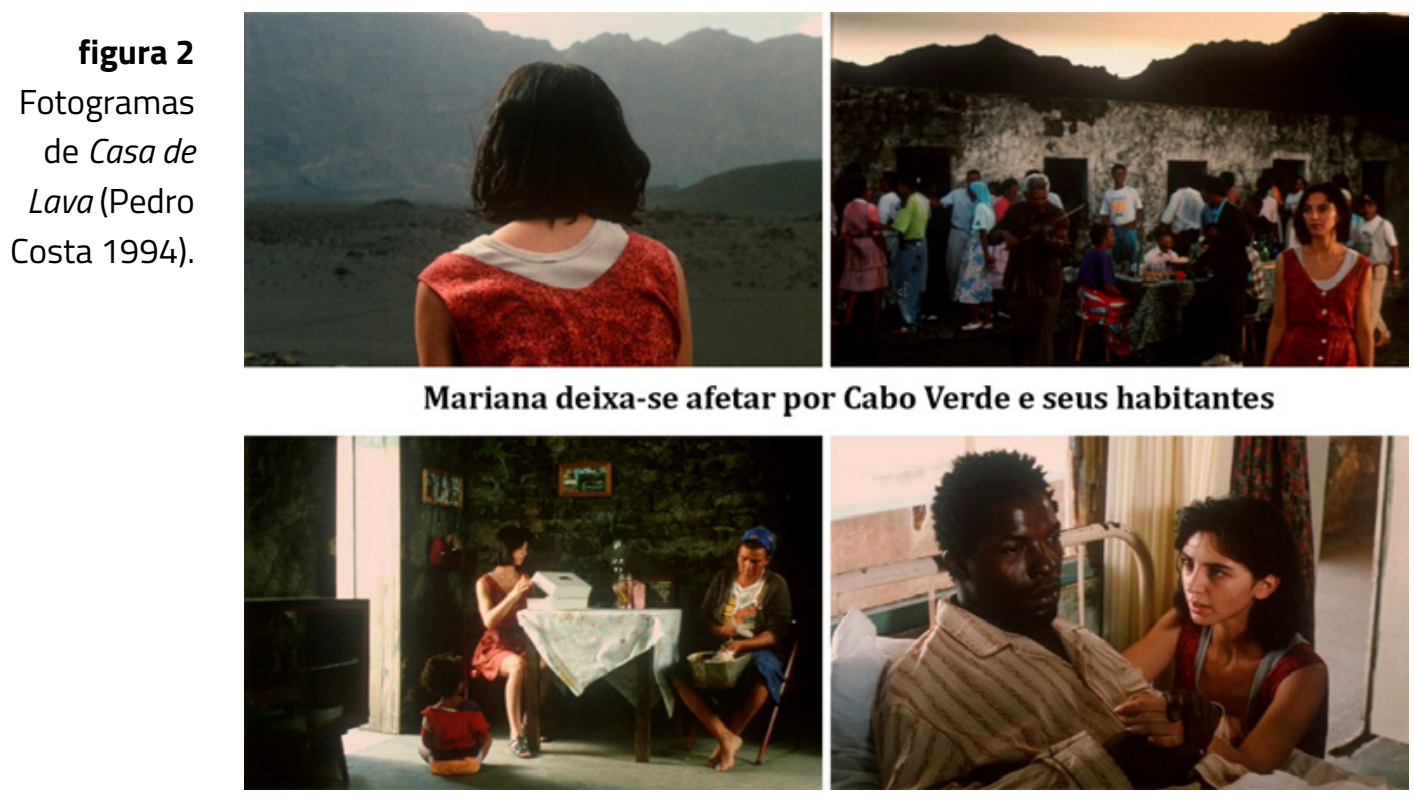

É um filme baseado no encontro, no afetar e ser afetado pelo contexto. Ele não se sente confortável em escrever um guião, pois o faz perceber que está a perder o contato com o local, com as pessoas ou com a realidade (Costa 2016b): "o princípio de um filme e a razão, normalmente estão associados a uma pessoa ou a várias pessoas ou a pessoas e sítios, que foi meu caso no princípio da relação com Fontainhas" (Costa 2016b). Por isso, a pesquisa é essencial no seu método. Somente ao conhecer as pessoas e suas relações com os locais onde habitam, é que surgem os gérmens dos filmes de Costa. E se apropria também do resultado do encontro do cineasta e sua câmera com esses sujeitos.

Durante a realização de Casa de Lava, em suas conversas com os moradores locais, foi requisitado ao realizador que levasse à Portugal presentes e cartas para quem estava além-mar. Ao regressar à Lisboa, Costa visitou o Bairro das Fontainhas, para onde era endereçada a maioria das cartas. Foi então que descobriu o local e as pessoas que fizeram parte de suas obras posteriores.

Fontainhas era uma comunidade formada, principalmente, por imigrantes cabo-verdianos, localizada no subúrbio de Lisboa, composta de casas humildes e vielas estreitas. 0 bairro foi demolido no começo dos anos 2000, e seus habitantes transferidos para um conjunto habitacional em outro bairro, o Casal da Boba, que não possui, entretanto, a vivacidade de Fontainhas. Costa teve seu primeiro contato com o bairro na década de 1990, ao regressar de Cabo Verde com as cartas. Fontainhas tornou-se seu campo de pesquisa, desde então. 

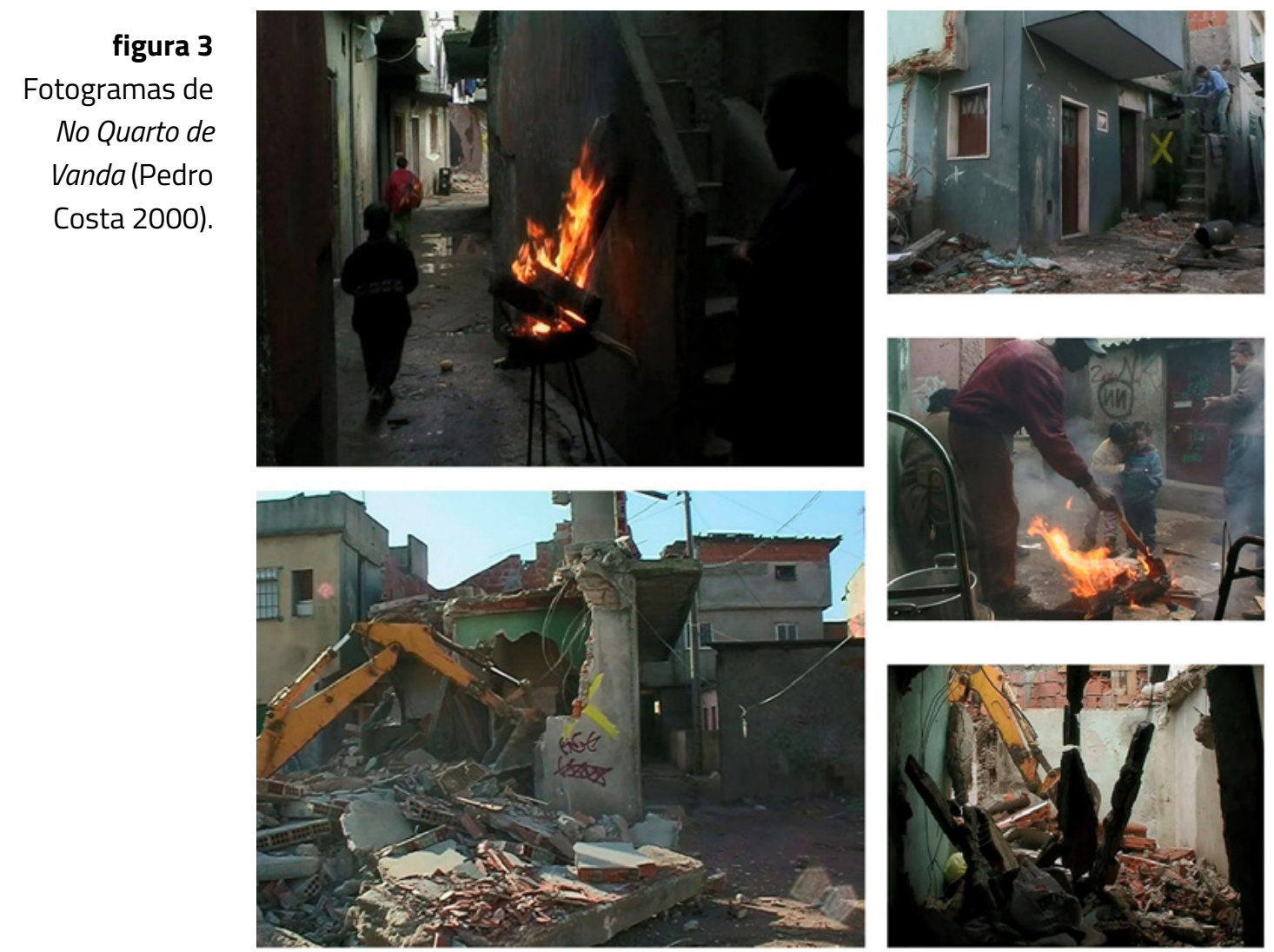

As mensagens facilitaram seu ingresso no bairro e o contato com as pessoas. A carta tornou-se uma metáfora para sua maneira de fazer filmes. Ele não sabe o conteúdo, nem das cartas e nem do filme que realiza, mas é possível ver as reações.

Logo que começou a filmar, o bairro começou a ser demolido e seus filmes subsequentes marcam esse processo de demolição. Juventude em Marcha (2006) mostra essa transição e a vida de alguns dos moradores na nova morada.

Foi em Fontainhas que Costa conheceu seus principais personagens, Vanda e Ventura, que viriam a ser atores de seus filmes seguintes: Ossos (1997), No Quarto de Vanda (2000), Juventude em Marcha (2006) e Cavalo Dinheiro (2014).

Quase uma década de pesquisa e contato com os moradores marcam o trabalho de Costa, que, após Ossos, abandona de vez o roteiro pré-concebido para mergulhar nas histórias de vida, sonhos, angústias e anseios dessas pessoas. 


\section{UM MÉTODO DEMOCRÁTICO}

A bricolagem se faz presente também na tessitura da trama, na realização do filme, por meio do trabalho com os atores. 0 enredo é criado, muitas vezes, a partir do material que os próprios "não" atores lhe fornecem. Aqui, presenciamos a influência do movimento punk, do DIY, assentada na busca de uma arte mais democrática, horizontal e menos hierárquica; na recusa em criar um roteiro, ao se apropriar do material dado pelos "não" atores.

Quando digo que o bairro conta, quero apenas dizer que todos os dias tinha à frente uma realidade que me levava mais longe do que a mera superfície que se cola aos olhos e à lente. o ventura, a Vanda, o Lento são prisioneiros de sua pequena história e da História. E, simultaneamente, são os guardas de sua prisão, desta minha prisão que é o filme e da qual eu sou o diretor. São eles os argumentistas... (Costa 2012, 29).

Nos últimos anos, Pedro Costa tem preferido não inventar um script. As histórias surgem a partir de um coletivo de pessoas que escrevem ou criam juntas seus atores e, por isso, chama seu método de democrático (Costa 2016a). Por sua vez, esses “não" atores são também encontrados por Costa.

Vanda Duarte foi encontrada no bairro das Fontainhas. Ela nunca havia trabalhado como atriz, mesmo assim, Costa lhe convidou para participar de Ossos. Ele já tinha o esboço de um enredo em mente, após ter lido em um jornal sobre a história de uma mulher que havia perdido o bebê em um banheiro. Também lhe vinha à cabeça uma atmosfera de gás... "Já tinha o gás e o bebê, faltava encontrar os rostos do bairro" (Costa 2012, 39). Foi quando conheceu Vanda e sua irmã Zita: "Chego ao bairro e, assim que a vejo, gosto logo dela, humanamente, plasticamente" (Costa 2012, 39). As duas irmãs apareciam como seres opostos e complementares; o que Vanda possuía de extrovertida, Zita guardava dentro de si. Costa não hesitou e as chamou para participar do filme. A princípio, Vanda recusara, alegando ter muito trabalho. Costa achou estranho, pois ouvira falar que ela passava o dia todo em seu quarto, inalando heroína. Após insistir, Vanda aceitou (Costa 2012, 39-44).

A personagem de Vanda foi criada em conjunto com ela: "inventamos uma personagem de empregada doméstica, um complô feminino, uma roda de mulheres à volta do rapaz perdido com o bebê" (Costa 2012, 41). Assim, surge o enredo de Ossos. As ideias iniciais de Costa e o complemento de Vanda e dos outros personagens, como uma verdadeira colagem de opiniões. 
Esse filme ainda foi realizado de maneira convencional - com argumento escrito, grande equipe e equipamentos de cinema -, e Costa tinha a intenção de que Vanda seguisse o que ele lhe propunha, mas, durante as filmagens, ela o surpreendia, e quando ele lhe pedia para chorar, ela nem ria e nem chorava, mantinha-se séria; quando lhe demandava dizer bom dia, dizia boa noite. Costa percebeu que era ela quem queria inventar, propor, até que ela o convidou para fazer um filme em seu quarto (Costa 2012, 4547) e o realizador aceitou. Assim, nasceu No quarto de Vanda (2000), quarto longa-metragem do diretor, no qual costa acompanha a rotina de Vanda, seu vício em fumar heroína, suas conversas com a irmã e vizinhos, seu relacionamento com a família, suas angústias e sonhos.

Portanto, na origem de [No quarto de] Vanda, também houve este desafio: enfrentar um real real, um jogo verdadeiramente documental. Mas era preciso que este convite de certa maneira documental fosse alimentado por uma ficção. Um documentário que não começa por uma ficção deste gênero não existe. Convidam-me para um sítio qualquer, gosto das pessoas, elas gostam de mim: é isto que faz um filme (Costa 2012, 47).

figura 4

Fotograma de No Quarto de Vanda 
Foram dois anos a filmar Vanda em seu quarto. Costa passava horas, às vezes até dias dentro das quatro paredes do quarto de Vanda. Isso foi possível após Costa adotar o digital, que permitiu, além da proximidade com Vanda e sua irmã, abandonar do uso de luz artificial que a película impunha e gravar muitas horas de materiais, pois o custo do digital é mais baixo, comparado ao $35 \mathrm{~mm}$.

Vanda e Costa tinham os temas, já que a base era fazer um filme com ela e com a família, no quarto, na casa, no bairro. Os rapazes e suas casas surgiram depois. A direção se dava da seguinte maneira, como explica o diretor:

Eram coisas relativamente simples, quase documentais, e depois, dentro desse documental tínhamos uns temas, uns tópicos que eram: como é que era o bairro há muitos anos, quando eras pequena, a escola, o pai, a mãe, enfim, coisas muito ligadas à vida dela e, portanto, quando começávamos qualquer cena, por exemplo, sobre a infância no bairro, o que se desenhava, o que acontecia na primeira vez era contar a história. o que eu fazia quando ela acabava e começava a repetição, portanto um trabalho de aperfeiçoamento daquela história; era eu escolher o que interessava e o que não interessava ao filme. Era assim também com Ventura ou Vitalina. [...] Na segunda tomada, no segundo contar da história já se reduziu bastante e já começa a se ter uma noção de uma linha, de onde é que partimos e onde chegamos. A partir daí é sempre uma espécie de redução (Costa 2016b) ${ }^{13}$.

Pedro Costa baseia-se na repetição. Em seu curso, o diretor destacou a influência de Charles Chaplin em sua maneira de dirigir os atores e até mesmo de conceber o filme, bem assim exibiu Unknown Chaplin (Kevin Brownlow e David Gill 1983), uma série de documentários que apresentam o processo de direção do cineasta. A série mostra como, apesar da improvisação, Chaplin repetia centenas de vezes um mesmo plano até estar perfeito e surgir a história. Muitas vezes, ele não possuía um roteiro escrito, começava o filme por gagues ${ }^{14}$ e esse quiproquó que era responsável por fazer surgir as cenas e os enredos. Como um jogo de tentativa e erro, se não desse certo, era apenas começar novamente.

No curso ministrado em Bolonha, Pedro enfatiza: "A pessoa entra no bar, pede algo, mas não tem moedas. Eu preciso filmar o antes e o depois. Preciso organizar o filme ao redor disso" (2016a). Assim como Chaplin, que parte de uma gague para compor sua narrativa.

13. Áudio da entrevista disponível.

14. Piada improvisada. 
Não sei em que momento começa a surgir alguma espécie de criação. Quando é que se cria um personagem, um fio da história. Eu não sei bem se é da ordem da criação, se é da ordem mais da repetição, e do fato de que nós quando começamos a trabalhar, já temos muitos dados adquiridos. Quero dizer, já há muita coisa e não é possível sair de alguns quadros que já estão impostos por estar a filmar com Ventura ou a Vitalina; um o fato de serem cabo-verdianos, outro de falarem uma certa língua, o outro terem uma certa personalidade, ou seja, eu nunca tento mudar, como outros realizadores, por exemplo, o tempo, o ritmo das pessoas. Prefiro que seja feito na montagem, nos planos (Costa 2016b)..$^{15}$

Pedro Costa respeita o que a pessoa tem a dizer, a contar e a maneira como a pessoa quer fazer isso. Ele corrige apenas pequenas coisas, que têm a ver com a luz, mas não com o tempo interno dos atores/personagens (Costa 2016b).

É nesse sentido que o diretor classifica suas obras como ficções, pois não considera seus filmes documentários observacionais. Ele interfere na escolha dos temas dos diálogos, pede para que se repita diversas vezes, corta-os.

\section{figura 5}

Fotograma de Cavalo Dinheiro (Pedro Costa 2014).

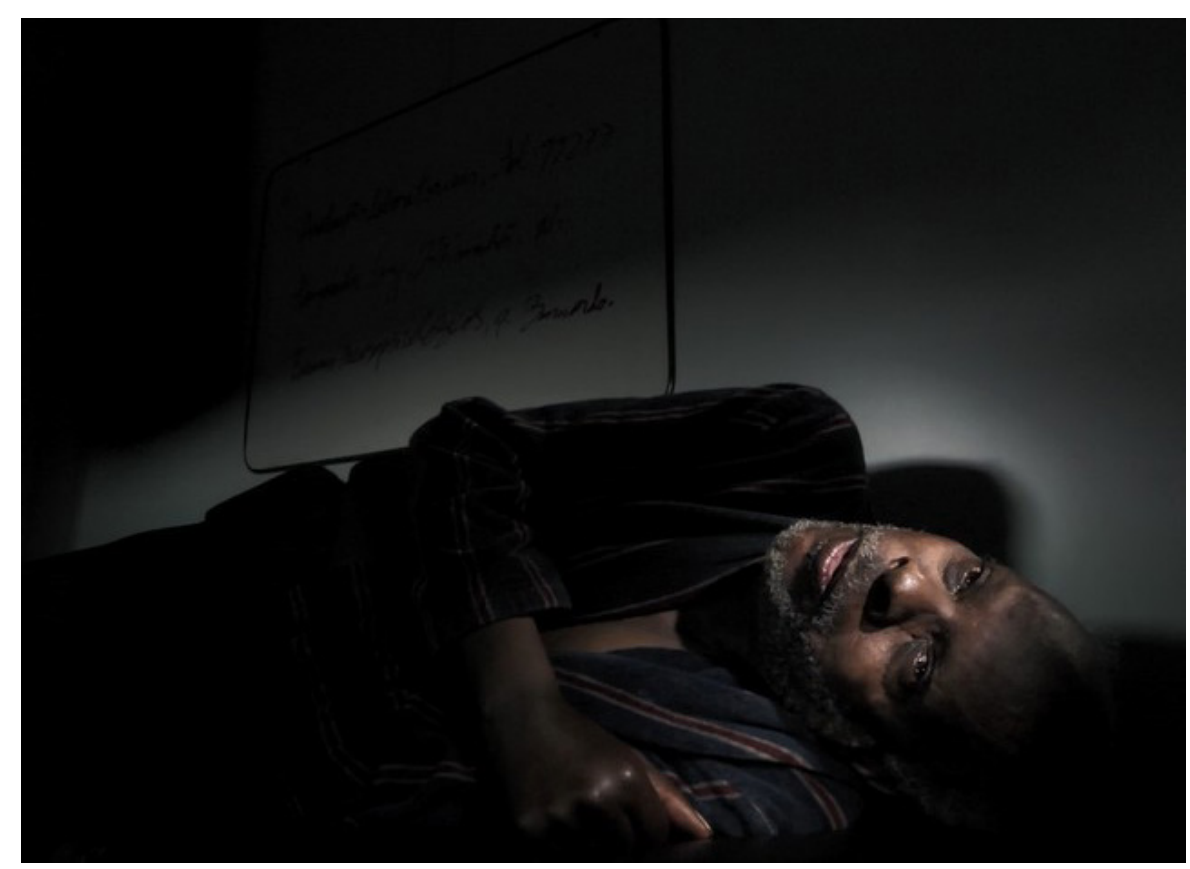

15 Áudio da entrevista disponível. 
Ventura foi o primeiro morador do bairro das Fontainhas. Costa o conheceu durante a filmagem de Ossos. Tornaram-se amigos, até que o diretor o convidou para fazer um filme. Tratava-se de Juventude em marcha (2006). Nele, Ventura é uma espécie de pai dos moradores do bairro. Sua condição de imigrante, a saudade de casa e, principalmente, da esposa Zulmira, que foi obrigado a deixar para trás, marcam a temática desse filme, que trata de dois exílios: o primeiro é quando esses imigrantes tiveram que deixar sua terra natal em busca de melhores condições de vida, saindo de Cabo Verde em direção à Portugal, e o segundo exílio desses atores personagens é quando têm que deixar o bairro onde estabeleceram laços para um outro frio e distante.

A carta que Ventura escreve à esposa é dita e repetida ao longo do filme:

Eu gostava de te oferecer cem mil cigarros / uma dúzia de vestidos daqueles mais modernos / um automóvel / uma casinha de lava que tu tanto querias / um ramalhete de flores de quatro tostões / mas antes de todas as coisas / Bebe uma garrafa de vinho bom / Pensa em mim (Juventude em marcha, 2006).

Robert Desnos, poeta surrealista francês, escreveu, nos anos 1940, de dentro de um campo de concentração, uma carta ${ }^{16}$ endereçada à sua esposa. Costa busca inspiração nessa mensagem e junto com Ventura cria uma versão da carta, em criolo, que nunca chegaria à sua esposa, mas que expressa o sentimento de quem tem a esperança de um dia se reencontrar... "Nem Desnos nem Ventura reencontraram as mulheres. Nem Desnos nem Ventura receberam sequer resposta a essas cartas. Nem Desnos nem Ventura verão as mulheres que amaram com os vestidos que sonharam" (Bénard da Costa 2009, 26).

Após perder sua casa, Ventura vaga imerso em um sentimento de nostalgia. Percorre tanto Fontainhas quanto a nova morada, no Casal da Boba, indo de casa em casa a visitar os filhos postiços. Uma dessas casas é a de Vanda, que tem agora uma filha e um companheiro e conta, entre outras coisas, que está limpa do vício.

São criações conjuntas, em um processo colaborativo, que Costa (2016c) exemplifica com o segurança que participou de Juventude em Marcha.

16100000 cigarros louros, doze vestidos de grandes costureiros, o apartamento da Rua de Seine, um automóvel, a casinha da mata de Campiègne, a de Belle-Isle e um raminho de flores de cinco tostões. Na minha ausência, compra à mesma as flores, que eu as pagarei. o resto, prometo-o para mais tarde. Mas, acima de tudo, bebe uma garrafa de bom vinho e pensa em mim (Bénard da Costa 2009, 26). 
Ele era mesmo segurança de um supermercado e escreveu seu próprio texto. Costa pediu apenas para ele falar que tem uma vida complicada e que no museu ganha mais dinheiro do que no supermercado, apesar de ele mesmo não trabalhar no museu. E o diálogo desenvolvido pelo segurança deu-se da seguinte maneira:

Vigiar este lugar não é como vigiar o mercado ao ar livre da minha terra. Aqui você empunha uma mãe de ferro com uma luva de veludo. Lá, é apenas uma mão de ferro. Nada além de miséria. Negros, brancos, ciganos, velhos, crianças... Todos roubam. Tanta fome e tristeza que te faz sentir-se mal. Sei do que estou falando. Aqui é outro mundo. Um mundo antigo, imperturbável. Ninguém grita ou corre ou cospe no chão. É elegante e fácil. Posso até tirar uma soneca. Então as tardes aqui na Arte Egípcia são sagradas. É um problema quando alguém como você aparece. Mas você não vê pessoas como eu ou você aqui com frequência. Somos deixados em paz (Juventude em Marcha 2006).

O rapaz, em suas falas, articulou elementos de sua memória ainda em Cabo-Verde, sua experiência como segurança de supermercado e sua experiência como imigrante negro, com o que seria trabalhar em um museu, o que ele imagina ser este trabalho. Como Costa afirma: "Tudo o que ele diz vem da ideia dele" (Costa 2016c).

O diálogo é peça importante no filme, e as falas e as ações do ator / personagem foram criadas em conjunto, no mesmo processo que Costa desempenhou no filme anterior. Esse processo também ocorreu em Cavalo Dinheiro (2014), em que Ventura foi igualmente protagonista.

Sobre Ventura, Costa revela: "o que ele estava a dizer, eu sabia que vinha dele, de uma experiência de vida dele" (Costa 2016c). E ainda: "É um conjunto de cultura pessoal, da vida dele, da experiência dele, um bocadinho da cultura da ilha, da vida lá no princípio, daqueles anos (de ser um filho dos anos 1950)". (Costa 2016c).

O diretor afirma que os diálogos desenvolvidos por Ventura nunca poderiam ter partido dele (Costa) ou de um argumentista, pois surgem da experiência de Ventura e se utilizam de palavras que não fazem parte do vocabulário do cineasta, como: vida jovem ou reportar, ao invés de lembrar. “Às vezes não tenho ideias porque é muito exterior a mim" (Costa 2016c).

Cavalo Dinheiro mergulha nos devaneios de Ventura, nas sombras e fantasmas que o assombram. Suas memórias, seu presente e sua imaginação se misturam e dão forma a um filme um tanto fantasmagórico, em 
relação a não se saber mais se os personagens vistos por Ventura são vivos ou mortos. Dinheiro é o nome do cavalo que Ventura deixou em Cabo Verde, o qual crê que tenha sido devorado por abutres, assim como foram devorados seus sonhos de uma vida melhor no país colonizador.

o passado de Ventura e o passado de Portugal misturam-se, colam-se, referem-se. Ele diz ter 19 anos, mas sabemos que não os tem. É essa memória da sua juventude, do seu passado em Cabo Verde, da chegada a Portugal, da Revolução de 1974, que se atualizam nas ações e diálogos de ventura.

Assim como o tempo se mistura, os lugares também o fazem. Cabo Verde, Portugal, manicômio, Fontainhas... existem na memória e na sua atualização. Apesar do fato de Fontainhas não existir mais, sua presença continua no filme, por intermédio do imaginário de Costa e de Ventura.

O processo de realização do filme se equipara aos anteriores: No Quarto de Vanda e Juventude em Marcha, com diálogos criados em conjunto, com depoimentos aperfeiçoados pela repetição e pelo corte, com o uso restrito de equipamentos.

Tal trabalho de direção, que prioriza a criação conjunta, já aparecera antes na história do cinema, assim como da Antropologia. Um dos maiores representantes desse tipo de filme é, sem dúvida nenhuma, o antropólogo-cineasta Jean Rouch. No cinema antropológico de Jean Rouch, essa colaboração, associada à visão dos interlocutores como sujeitos, tornou-se conhecida como antropologia compartilhada.

Na antropologia compartilhada utilizada por Rouch, os personagens não são vistos somente como objetos de estudo, mas como sujeitos do filme, pois há um processo colaborativo entre o diretor e os sujeitos na sua construção. Tal colaboração se desenvolve na improvisação desses sujeitos, na criação da história em conjunto e nos comentários em off que os "não" atores tecem em seus filmes mesmo depois de prontos.

São perspectivas que se unem, pois o filme nasce do encontro. "Rouch marca seus filmes com as múltiplas vozes presentes em campo e na relação de troca que se dá na pesquisa etnográfica/cinematográfica, o produto do encontro é fruto da simbiose de ambas as perspectivas" (Barbosa, Cunha e Hikiji 2006, 289).

No cinema e no teatro, quando o texto é criado em conjunto entre o diretor e os atores, sejam eles inspirados na vida desses atores ou não, chama-se de processo colaborativo. Podemos ver esse processo no cinema de costa, principalmente nos filmes No Quarto de Vanda, Juventude em Marcha e Cavalo Dinheiro. 


\section{CONTADOR DE HISTÓRIAS}

É na montagem que Pedro Costa desempenha a função de contador de histórias. É nesse momento da realização do filme que ele encadeia todo o material coletado. É aqui que ele se torna o completo bricoleur. "É o momento mais importante da construção" (Costa 2016a), pois é a fase em que o diretor atua com mais autonomia e autoridade, na qual escolhe o tempo certo dos planos, os takes que ficaram melhores. É a união dos planos que vai dar a narrativa dos filmes. Vanda, Ventura e Vitalina contaram suas histórias, agora é o momento de o diretor contar a dele. ${ }^{17}$

Em No Quarto de Vanda, Juventude em Marcha e Cavalo Dinheiro, o processo se deu na sala de edição, pois foram realizados em vídeo. Em No Quarto de Vanda, por exemplo, o diretor possuía 100 horas de material gravado, o que levou duas semanas só para assistir.

Costa trabalha com a ideia de que cada cena tenha pontos de contato com as outras, não necessariamente em seguida, mas que uma fala dita em algum momento do filme repercuta posteriormente na narrativa, por exemplo (Costa 2016b).

Seus filmes seguem a ordem sintática da parataxe, que é como se denomina na gramática a sequência de frases sem uma conjunção subordinativa ou coordenativa, isto é, sem dependência entre os termos. Na montagem cinematográfica, a parataxe configura-se como uma montagem em justaposição, em que as cenas não são subordinadas umas às outras; não há hierarquias, e um plano, uma cena ou uma sequência são tão importantes quanto outros.

A parataxe é uma prática comum no cinema de colagem, ao contrário da hipotaxe, na qual há uma maior subordinação, isto é, dependência e encaixe entre os termos ou blocos de significação, a criar uma narrativa. A hipotaxe ocorre na decupagem clássica dramática, no cinema convencional, na qual a montagem é feita de acordo com as convenções que permitem que ela se torne transparente.

Em O Discurso Cinematográfico, Ismail Xavier (2005) diferencia diversos tipos de decupagem existentes no cinema. Na decupagem clássica, que é a mais corriqueira no cinema, para mostrar um fato, o diretor realiza diversos cortes dentro de uma mesma cena, uma mudança "[...] do ponto de vista para mostrar de um outro ângulo ou de uma outra distância o 'mesmo fato' que, supostamente, não sofreu solução de continuidade,

17 Além da montagem, o olhar do diretor, a escolha dos enquadramentos, a iluminação, entre outros, são formas de contar a história e são opções do cineasta. 
nem se deslocou para outro espaço" (Xavier 2005, 29); como o uso de plano e contraplano, por exemplo. Tal a situação dá a impressão de que a cena foi filmada de uma só vez.

Já no cinema de Costa, as cenas são mais longas, na maioria das vezes, ininterruptas, e os elos entre as cenas são criados a partir do encadeamento dos planos e configuram-se em nível de temas. Inclusive, podendo alguns desses blocos serem apresentados em separado do restante do filme. Por exemplo, a cena do elevador, em Cavalo Dinheiro, que se tornou um bloco independente e foi transformada no curta Sweet Exorcism (2012), para compor o filme Centro Histórico (Pedro Costa et al. 2012), feito com episódios de diversos cineastas.

figura 6

Fotogramas de Cavalo Dinheiro (Costa 2014).
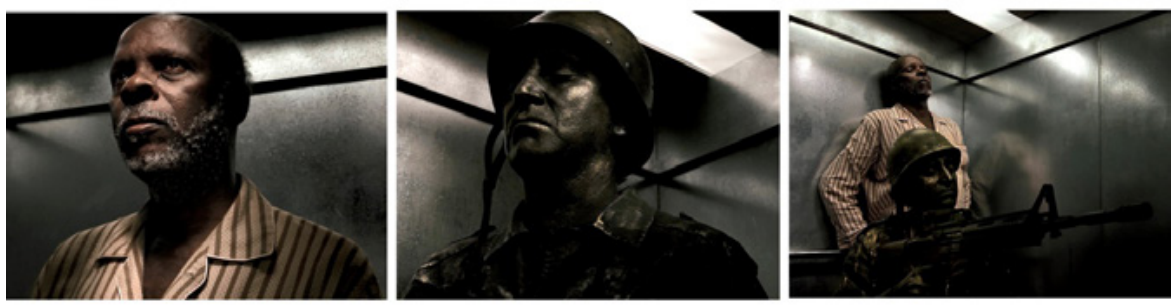

Pedro Costa sobrepõe o áudio dessa cena em diversas camadas. A voz (em direto) de Ventura é mesclada com diversas vozes fantasmagóricas em off (do próprio Ventura, do soldado, de uma criança). Uma música também invade a banda sonora. Pedro Costa realiza a colagem sonora. Em No Quarto de Vanda, por exemplo, os ruídos externos da demolição do bairro invadiam as cenas internas e foram incorporados aos diálogos, reforçando o ritmo do filme.

A colagem imagética é explícita na introdução de Cavalo Dinheiro, por exemplo, que começa com fotografias de Jacob Riis, fotógrafo dinamarquês, ligado aos movimentos sociais norte-americanos no final do século XIX, o qual documentou as favelas nova-iorquinas.
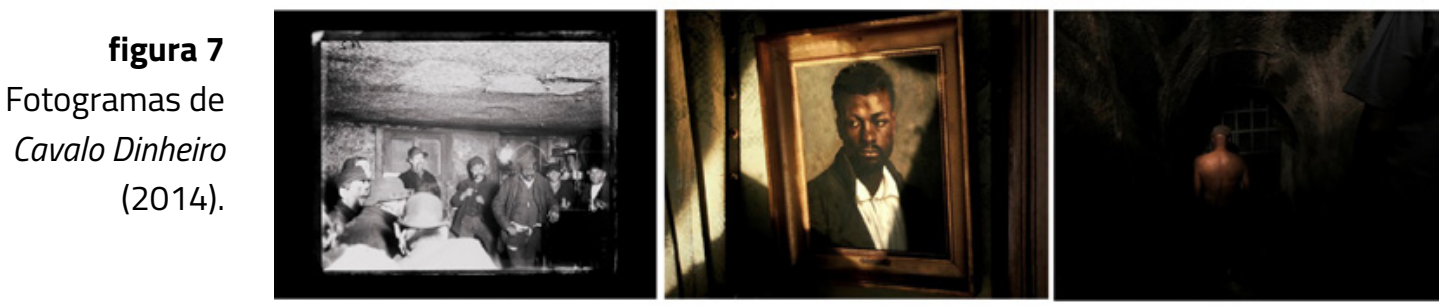

Nesses screenshots, é possível ver como Costa trabalhou com a bricolagem em seu filme. Nos primeiros planos, são mostradas as fotografias de Riis. São fotografias em preto e branco, com suas bordas desgastadas 
pelo tempo, assim como sua superfície. São 12 as fotografias mostradas, por cerca de seis segundos cada. Logo após, aparece o quadro emoldurado de um homem negro, pendurado em uma parede, a qual não conseguimos distinguir de onde se trata. Segue um movimento panorâmico de câmera e vemos um homem, também negro, de costas, a descer uma escada escura; trata-se de Ventura.

A ligação que as fotografias constituem com o plano a seguir não são da ordem da subordinação, mas sim do encadeamento. Assim acontece com as sequências seguintes, dos delírios de ventura.

Sua montagem elíptica cria um efeito de opacidade, ao contrário da transparência. Ele utiliza tanto elipses temporais quanto espaciais. Em Cavalo Dinheiro, Ventura é transportado para o passado por meio de seus diálogos e dos locais nos quais se encontra. As elipses ajudam a confundir presente e passado.

Em Juventude em Marcha, por exemplo, a cena em que Ventura está na casa de Lento é cortada, por meio de uma elipse espacial, para um quadro de Rubens, no Museu Gulbenkian, edifício que Ventura ajudara a construir, mas que nunca usufruiu. (Martin 2009; Rancière 2009; Silveira 2015). Temos aí tanto uma elipse temporal como espacial. E assim se seguem todas as sequências seguintes.

Desse modo, a parataxe e a elipse empregadas na montagem por Pedro Costa fazem a costura de seus filmes. É nessa etapa do processo do bricoleur que o trabalho ganha forma.

\section{CONSIDERAÇÕES FINAIS}

O cinema de Pedro Costa constitui um material rico tanto para estudos na área da Antropologia quanto do Cinema. 0 diretor utiliza alguns recursos do filme etnográfico, como filmar as pessoas em seu próprio contexto, utilizando com isso "não" atores; realiza uma extensa pesquisa de campo, e os sujeitos de seus filmes tornam-se também os argumentistas, pois são obras que possuem a colaboração de seus interlocutores; também utiliza alguns recursos do cinema ficcional, como a direção de atores, a repetição, a mixagem de som, entre outras. Este artigo não visa definir o gênero de suas obras, mas sim os contextos nos quais foram realizadas e como sua realização ocorreu.

Procurei explorar o lado bricoleur de seu modus operandi, pois a metodologia empregada pelo diretor assume uma postura similar à dos jovens do movimento punk, na busca de uma cultura em que qualquer indivíduo possa participar do processo cultural (DYI) - o que Pedro costa denomina de método democrático - e na recusa de se fazer um cinema dentro do mainstream. 
Para isso, interpretei seu cinema, assim como define o próprio diretor, como colagens, ao invés de criações. Pedro Costa utiliza materiais encontrados e não criados (locações, "não" atores, histórias). 0 diretor não usa roteiro previamente escrito, uma vez que os diálogos partem dos próprios “não" atores, a partir de temas que o diretor propõe, assim como não visa criar uma história com começo-meio-fim. As cenas e os planos se colam de acordo com seu ritmo, com o seu desenvolver, não de acordo com uma história que o diretor imaginou previamente.

Neste artigo, não pretendi analisar cenas, planos ou sequências de seus filmes, pois o foco está na concepção, no seu método. o que me interessou na análise foi o material extrafílmico, que explicita seu método de direção.

Os elementos com os quais Costa trabalha são aqueles dados pelos lugares onde filma e pelas pessoas que neles habitam. Costa lida com os sonhos, com a memória e com os devaneios das pessoas que participam de seus filmes. Na concepção de No Quarto de Vanda, Juventude em Marcha e Cavalo Dinheiro, isso é mais explícito.

\section{REFERÊNCIAS BIBLIOGRÁFICAS}

Artecapital. n.d. Entrevista Pedro Costa. Disponível em <http://www.artecapital.net/ entrevista-158-pedro-costa> Acesso em: 15 maio 2016.

Aumont, Jacques. 2004. As teorias dos cineastas. Campinas: Papirus.

Barbosa, Andrea; Cunha, Edgar T.; Hikiji, Rose S. G. 2006. O vídeo e o encontro etnográfico. Cadernos de campo, n. 14/15: 287-298.

Barroso, Bárbara; Ribas, Daniel. 2008. No cinema português. Devires, v. 5: 136-159.

Bénard da Costa, João. 2009. O Negro é uma cor ou o cinema de Pedro Costa. In: Cabo, Ricardo Matos (org). Cem mil cigarros. Lisboa: Orfeu Negro.

Bivar, Antônio. 2001. O que é punk. São Paulo: Brasiliense.

Caiafa, Janice. 1985. Movimento punk na cidade a invasão dos bandos sub. Rio de Janeiro: Jorge Zahar.

Costa, Pedro. 2013. Casa de lava - caderno. Lisboa: Pierre von Kleist.

. 2016a. Depoimento extraído de seu curso em Bolonha, na Itália, ministrado entre os dias 23 e 25 de abril. 
. 2016b. Entrevista concedida a Kelen Pessuto, em 15 de junho de 2016.

2016c. Entrevista concedida a Kelen Pessuto em 10 de agosto, de 2016.

Costa, Pedro; Neyrat, Cyril; Rector, Andy. 2012. Um melro dourado, um ramo de flores, uma colher de prata. Lisboa: Orfeu Negro e Midas Filmes.

Delle Vecche, Angela. 1996. Cinema and painting. How art is used in film. Austin: University of Texas Press.

Eduardo, Cléber. 2010. Um: resgate do mistério. In: MAIA, Carla; DUARTE, Daniel Ribeiro; MOURÃo, Patrícia (orgs.). O cinema de Pedro Costa. Lisboa, São Paulo, Rio de Janeiro, Brasília: Centro Cultural Banco do Brasil.

Gallagher, Tag. 2009. Straub Anti-Straub. In: CABO, Ricardo Matos (org). Cem mil cigarros. Lisboa: Orfeu Negro.

Gallo, Ivone. 2010. Por uma historiografia do punk. Projeto História, 41: 283-314.

Gorin, Jean-Pierre. 2009. Nove notas sobre onde jaz o teu sorriso?. In: CABO, Ricardo Matos (org.). Cem mil cigarros. Lisboa: Orfeu Negro.

Lemos, Paulo Bettencourt. 2011. A importância do punk em Portugal. Dissertação, Universidade de Coimbra, Coimbra.

Lévi-Strauss, Claude. 1989. O pensamento selvagem. Campinas: Papirus.

Martin, Adrian. 2009. A vida interior de um filme. In: CABO, Ricardo Matos (org.). Cem mil cigarros. Lisboa: Orfeu Negro.

Pessuto, Kelen. 2011. O 'espelho mágico' do cinema iraniano: uma análise das performances dos "não" atores nos filmes de arte. Dissertação, Unicamp, Campinas.

Pessuto, Kelen. 2017. Made in Kurdistan. Etnoficção, infância e resistência no cinema curdo de Bahman Ghobadi. PhD Thesis. Universidade de São Paulo, São Paulo.

Rancière, Jacques. 2009. Política de Pedro Costa. In: Cabo, Ricardo Matos (org.). Cem mil cigarros. Lisboa: Orfeu Negro.

2013. O destino das imagens. Rio de Janeiro: Contraponto.

Silveira, Luciano Viegas. 2015. Montagem elíptica: efeito de opacidade no cinema de Pedro Costa. 2015. Monografia, Universidade Federal do Rio Grande do Sul, Porto Alegre.

Stam, Robert. 2013. Introdução à teoria do cinema. Capinas: Papirus. 
Xavier, Ismail. 2005. O discurso cinematográfico - a opacidade e a transparência. São Paulo: Paz e Terra.

\section{FILMOGRAFIA}

Brownlow, Kevin; Gill, David. 1983. Unknown Chaplin. Reino Unido, cor, 60', DVD.

Costa, Pedro. 1989. O Sangue. Lisboa, Portugal, pb, 95', 35mm. 1994. Casa de Lava. Portugal, França, Alemanha, cor, 110', 35mm. 1997. Ossos. Portugal, França, Dinamarca, cor, 94', 35mm. 2000. No Quarto de Vanda. Lisboa, Portugal, cor, 170', DVD. . 2001. Onde Jaz o Teu Sorriso? Portugal, França, pb and cor, 104', DVD. 2006. Juventude em Marcha. Portugal, França, Suíça, cor, 156', DVD. 2009. Ne change rien. Portugal, pb, 100', DVD.

2012. Segmento Sweet Exorcism. In: Costa et al. Centro histórico. Portugal, cor, 80', DVD.

2014. Cavalo Dinheiro. Portugal, cor, 103', 35mm.

Godard, Jean-Luc. 1988-98. Histoire(s) du cinema. França, cor, 51', DVD.

Tourneur, Jacques. 1943. I Walked with a Zombie. Estados Unidos, pb, 69', DVD.

\section{KELEN PESSUTO}

Doutora em Antropologia Social pela USP. Mestre em Artes pela Unicamp. Possui graduação em Comunicação Social com habilitação em Cinema pela Fundação Armando Álvares Penteado - FAAP (2003). Atriz formada pelo Teatro-Escola Célia Helena. Trabalhou como Arte-Educadora na Casa do Teatro. É membro dos Grupos de Pesquisa: NAPEDRA - Núcleo de Antropologia, Performance e Drama (USP), GRACIAS (Grupo de Antropo-

recebido 05.07.2016 aprovado 17.12 .2016 logia em Contextos Islâmicos e Árabes), na USP de Ribeirão Preto e GRAVI (Grupo de Antropologia Visual) no Departamento de Antropologia da USP. Suas pesquisas atuam principalmente nos seguintes temas: cinema iraniano, antropologia visual, antropologia da performance, islã e teatro. 